\title{
RESENHA CRÍTICA DA OBRA TEXTO E LEITOR: ASPECTOS COGNITIVOS DA LEITURA DA AUTORA ANGELA KLEIMAN
}

\section{KLEIMAN, Ângela. TeXto E Leitor: ASPectos Cognitivos DA leitura. 16. ed. Campinas, São Paulo: Editora Pontes, 2016.}

\author{
Rute Kaizer de Carvalho \\ Mestra em Educação, Filosofia e Formação Humana pela Uninove. \\ São Paulo - SP, Brasil. \\ rkaizer2016@outlook.com
}

Resumo: Texto e leitor: Aspectos cognitivos da leitura completa 28 anos de publicação. Contudo, as teorias cognitivas sobre a compreensão textual nele apresentadas não são ultrapassadas, tampouco errôneas. O que torna essa mais recente edição diferente da primeira é o fato de que a autora torna explícito o que antes estava implícito: ler envolve mais do que o ato da compreensão. Na leitura se englobam o que foi entendido e o que foi mal interpretado, a experiência individual e o engajamento social.

Palavras-chave: Compreensão textual, Processo de leitura, Teorias cognitivas.

Angela Kleiman construiu uma vida profissional dedicada aos estudos de Linguística e ainda continua a atuar como professora titular e colaboradora já aposentada, na Universidade Estadual de Campinas. Licenciou-se em Linguística na University of Illinois, EUA. Em 1982, coordenou a implantação do Departamento de Linguística Aplicada no Instituto de Estudos da Linguagem da Unicamp e a criação dos cursos de mestrado e doutorado do mesmo departamento. Com base em sua longa e intensa experiência na área de Linguística Aplicada, publicou quatro livros sobre leitura, um livro sobre gramática e um outro abordando o tema da metalinguagem. Ela também organizou coletâneas sobre 
leitura, letramento e formação do professor. Kleiman fundou o núcleo de pesquisa "Letramento do Professor", da Unicamp. Ela é considerada um dos grandes expoentes nacionais da Linguística e do processo de ensino e aprendizagem de leitura.

Texto e leitor: Aspectos cognitivos da leitura completa 28 anos de publicação. Teve origem numa série de palestras ministradas a alunos de mestrado e professores de língua materna na segunda metade da década de 80 do século XX. Contudo, as teorias cognitivas sobre a compreensão textual nele apresentadas não são ultrapassadas, tampouco errôneas. O que torna essa mais recente edição diferente da primeira é o fato de que a autora torna explícito o que antes estava implícito: ler envolve mais do que a ato da compreensão. $\mathrm{Na}$ leitura se englobam o que foi entendido e o que foi mal interpretado, a experiência individual e o engajamento social.

O livro tem menos de cem páginas e foi dividido em 4 capítulos: “O conhecimento prévio na leitura", "Objetivos e expectativas na leitura", "Estratégia de processamento de texto", e "Interação na leitura de texto". Com uma linguagem simples, concisa e objetiva, Kleiman aborda os aspectos que envolvem a leitura e compreensão textual.

No primeiro capítulo, a autora dá início às considerações dela explicando e exemplificando os tipos de conhecimentos ativados durante o exercício da leitura, que culminarão no momento da construção de um significado. Ainda nesse capítulo, somos levados a atentar para o fato de que o leitor não pode ser um mero receptor passivo, considerando-se que uma leitura proficiente se faz mediante a busca de conhecimentos linguísticos, textuais e conhecimentos gerais relevantes, que auxiliam no processamento das informações contidas no texto e sua compreensão.

Kleiman discorre, no segundo capítulo, sobre a importância do desenvolvimento de duas atividades metacognitivas para a compreensão textual, a saber: traçar os objetivos de uma leitura e formular hipóteses, que farão o leitor deduzir informações que estão por vir conforme avança na leitura. E a relevância dessas atividades incide na possibilidade de o leitor refletir e controlar, de forma consciente, o seu próprio conhecimento, atuação e capacidade. A autora enfatiza que as hipóteses formadas durante o processo são testadas e evidenciadas, ou não. E os objetivos que foram previamente definidos não apenas aperfeiçoam o ato da leitura, mas também da produção textual.

Encontramos no capítulo três a explicação de como o leitor consegue interpretar as marcas formais de um texto que estabelecem a coesão e constroem uma macroestrutura. Cumpre observar 
elementos como pontuação, classes de palavras, agentes coesivos e regras de linearidade, entre outros, cooperam na concretização do significado. Nesse sentido, o terceiro capítulo apresenta as principais estratégias para um processamento textual eficiente.

A esta altura, Kleiman já nos contemplou com uma análise da natureza exata das estratégias cognitivas do leitor. Entretanto, no quarto capítulo, restou à autora aludir à interação e cumplicidade entre o autor do texto e o leitor, visto que a leitura é um ato social. Ela nos fala da responsabilidade de ambos para a compreensão da mensagem. Sendo assim, o autor deve produzir um texto coerente, atraente e prazeroso. E o leitor deve ser um sujeito ativo nesse processo, e não passivo. Deve ser capaz de se posicionar de forma crítica diante do texto.

À guisa de conclusão, creio que esse pequeno livro provoca uma série de reflexões importantes sobre o ato da leitura. E aponta estratégias práticas e bem estruturadas que promovem uma leitura eficaz. Portanto, essa obra atende melhor o público docente, porque fornece teorias cognitivas sobre a compreensão textual e incentiva a proposta de atividades que não trivializem o exercício da leitura, mas o elevem a um status de prática pedagógica que otimiza a aprendizagem dos discentes. 